\title{
Paths to the unknown: dispersal during the early life of fishes ${ }^{1}$
}

\author{
Hubert Keckeis, Catriona Clemmesen, Paul Humphries, and Su Sponaugle
}

\begin{abstract}
The special issue brings together selected contributions from the 39th Annual Larval Fish Conference hosted by the University of Vienna, Austria, and presents the latest research and understanding of dispersal patterns and processes of early life stages of fishes of various aquatic environments around the world (open ocean, coastal areas, estuaries, and rivers). An important component of this compendium is to indicate new approaches and to outline the importance of integration of information about movements and dispersal for recruitment, population dynamics, species conservation, and management issues.

Résumé : Le présent numéro spécial réunit des communications choisies présentées au 39e congrès annuel sur les larves de poisson, qui s'est tenu à l'Université de Vienne (Autriche), et présente les plus récents travaux, et la compréhension qui en découle, sur les motifs et processus de dispersion des premiers stades de vie de poissons de différents milieux (haute mer, zones littorales, estuaires et rivières) aux quatre coins du monde. Un aspect important de ce recueil est qu'il décrit de nouvelles approches et souligne l'importance de l'intégration de l'information sur les déplacements et la dispersion pour l'étude du recrutement, de la dynamique des populations, de la conservation des espèces et des enjeux touchant à la gestion. [Traduit par la Rédaction]
\end{abstract}

The special issue brings together selected contributions from the 39th Annual Larval Fish Conference hosted by the University of Vienna, Austria, and presents the latest research and understanding of dispersal patterns and processes of early life stages of fishes. The main aim was to identify and describe the abiotic (e.g., temperature, habitat, hydraulics, hydrodynamics) and biotic (e.g., growth, feeding, genetics, energetics, species specificity, species interactions, development, morphology, life history) factors that influence the capacity or outcome of larval fish dispersal patterns and processes. An important component of this compendium is to outline the consequences of these findings for recruitment, population dynamics, conservation, and management in different aquatic environments around the world.

Overall, 15 contributions from 13 countries present information about changing morphometric relationships during early ontogeny and the consequences for dispersal, field observations of spatiotemporal dispersal patterns in rivers, estuaries, and oceans, extent of and connectivity with spawning grounds, patterns of settlement (recruitment) to reefs, behavior patterns of fish larvae in flow, and dispersal modelling (Table 1). The largest number of the studies was conducted in freshwater environments, seven in rivers and one in a fluvial lake, followed by investigations in marine environments (five), and two that analyzed the spatiotemporal distribution of larvae in estuaries. Ten of the studies were conducted in the field; three studies report findings of in vitro experiments and cultured individuals, and two studies summarize published knowledge about larval dispersal in oceans and rivers. The primary method for obtaining information about dispersing larvae is active net sampling in the marine environment and passive drift nets in rivers (Table 2). The length of studies ranges between 1 and 12 months: five studies focus on a single species; two studies focus on catadromous eels; and eight studies examine multispecies assemblages.

Knowledge of the dispersal ecology of the early life stages of fishes is urgently needed (Lechner et al. 2016) for further understanding of population dynamics, for environmental protection and species conservation, for fisheries management, and restoration ecology. Previous studies have revealed high larval mortality rates and, despite highly variable hydrodynamic conditions, unexpectedly high levels of self-recruitment in several oceanic environments (coastal and reef systems; Pineda et al. 2007). Studies in fast-flowing rivers, where most offspring are assumed to be transported downstream, have revealed that early stages can settle in close vicinity to release points or even move upstream in the nearshore zones (Schludermann et al. 2012). To obtain more information on recruitment and population connectivity, knowledge of the origin of larvae (i.e., location and extent of spawning grounds, time of reproduction), their trajectories from spawning areas to nursery habitats (path, duration, distance), as well as information about the quantity and specific characteristics of dispersers is critical. Early paradigms of passive dispersal of early stages of fish have been challenged by findings that clearly showed the capacity of larvae to orient and move directionally towards nursery habitats (Leis et al. 2011). Irrespective of the system (marine-freshwater, lotic-lentic), the knowledge of speciesspecific, autecological requirements of spawning areas, connectivity between spawning areas and nursery habitats, as well as survival during drift periods is still rather limited.

Received 24 November 2017. Accepted 27 November 2017.

H. Keckeis.* University of Vienna, Department of Limnology and Oceanography, Althanstrasse 14, 1090 Vienna, Austria.

C. Clemmesen.* GEOMAR Helmholtz Centre for Ocean Research Kiel, Düsternbrooker Weg 20, 24105 Kiel, Germany.

P. Humphries.* Charles Sturt University, Institute for Land, Water and Society, P.O. Box 789, Albury NSW 2640, Australia.

S. Sponaugle.* Oregon State University, Department of Integrative Biology, 2030 SE Marine Science Drive, Newport, OR 97365, USA.

Corresponding author: Hubert Keickeis (email: hubert.keckeis@univie.ac.at).

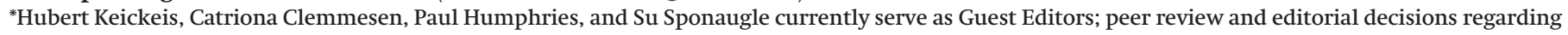
this manuscript were handled by Yong Chen.

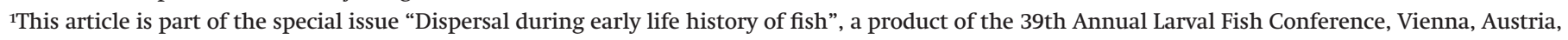
12-17 July 2015.

Copyright remains with the author(s) or their institution(s). Permission for reuse (free in most cases) can be obtained from RightsLink. 


\section{Pagination not final (cite DOI) / Pagination provisoire (citer le DOI)}

Table 1. Research topic, corresponding author, type of study, and site of investigation of all contributed papers for the special issue on dispersal of larval fish.

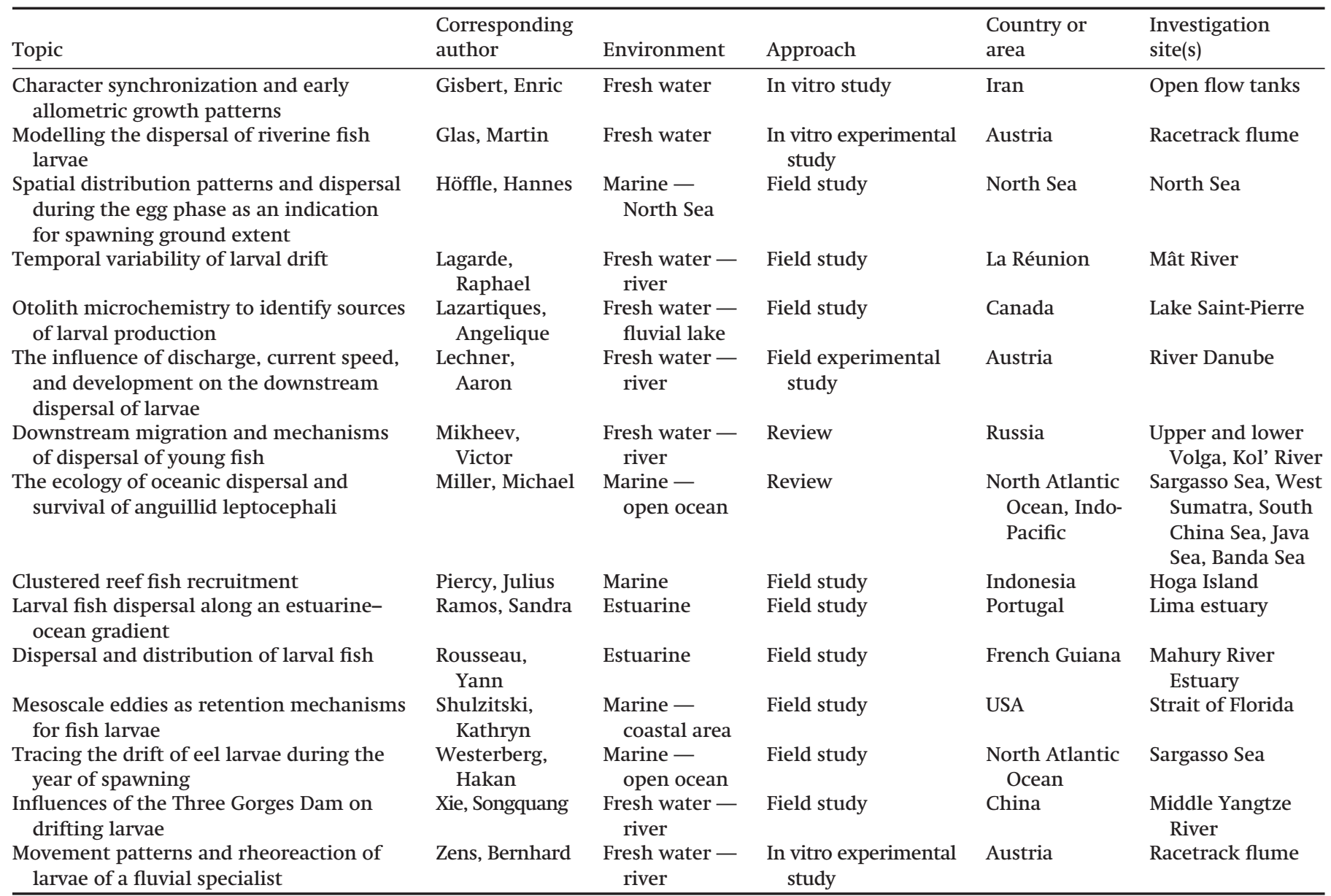

Defining the area of reproduction remains a challenging research topic in many different aquatic systems (oceans, rivers, lakes), as information necessary for conservation and management for many species is simply not available in the required detail. In this issue, three studies present new information about the sources of larval production. Höffle et al. (2018) show that although the spawning grounds of commercially important demersal fish species in the North Sea appear broadly constant, the centers of egg abundance vary yearly. Moreover, environmental factors, such as temperature, salinity, bottom depth, and density gradient, were important explanatory variables for the probability of occurrence and abundance of eggs. Lazartigues et al. (2018) used biochemical analysis of otoliths to measure the contribution of different spawning areas to the yearly production of a species of high fisheries importance. This study provides, for the first time, detailed, qualitative, and quantitative information on the recruitment process with regard to the connectivity of spawning areas and nurseries in a large fluvial lake system. These data are essential for the management and rebuilding of the fish stocks and shed new light on fish population dynamics in large freshwater systems.

Another approach by Westerberg et al. (2018) to locate the spawning area and time of European (Anguilla anguilla) and American (Anguilla rostrata) eels used backtracked trajectories and spawning times back-calculated from individual length and growth rates to show that a large portion of the larvae are trapped in a retention area south of the Subtropical Frontal Zone. There is large interannual variability in the leptocephali that escape and become entrained in the Gulf Stream system, due to prevailing oceanographic and climatic factors that alter the dispersion from the retention area. Miller and Tsukamoto (2017) review the state of knowledge of the biology and ecology of oceanic dispersal of leptocephali, summarizing information on spawning areas, food and feeding, transport, and the consequences for recruitment.

Whereas retention may be disadvantageous for eel larvae, these mechanisms play an important role in self-recruitment in oceanographically dynamic regions. Shulzitski et al. (2018) demonstrate the importance of mesoscale eddies for retention of locally spawned larvae. They describe species-specific and temporally variable impacts of these vortices on larval distribution and transport and differences in larval survival inside and outside of eddies. Retention mechanisms also may play a crucial role for dispersal and recruitment for fish inhabiting lotic freshwater environments (Schiemer et al. 2001).

Owing to the continuous movement of water, it has been assumed that early stages of fish in rivers behave like passive particles. Pavlov and Mikheev (2017) outline how the drift of larvae from several riverine fish species in different rivers reflect movements between well-defined habitats and that the adaptive value of downstream migration is not only for dispersal. By maintaining aggregations and synchrony of migratory activity, downstream movement also promotes the integrity of the populations. An experimental study by Zens et al. (2018) that analyzed individual movement trajectories of a fluvial fish species showed that swimming activity, direction of movement, and orientation towards a current vector led to larval dispersal paths and distances that deviated from those of passive particles, even at overcritical current situations. The movement patterns observed in this study 
Table 2. Basic information about sampling method, sampling periods, investigated taxa or species, and applied analysis techniques.

\begin{tabular}{|c|c|c|c|c|c|c|c|c|}
\hline Topic & Sampling method & $\begin{array}{l}\text { Sampling } \\
\text { period }\end{array}$ & Daily period & $\begin{array}{l}\text { Sampling } \\
\text { interval }\end{array}$ & Parameter & Taxa & $\begin{array}{l}\text { Species } \\
\text { identification }\end{array}$ & $\begin{array}{l}\text { Analysis-statistical } \\
\text { procedures }\end{array}$ \\
\hline $\begin{array}{l}\text { Character } \\
\text { synchronization } \\
\text { and early } \\
\text { allometric } \\
\text { growth patterns }\end{array}$ & Dip net (fish culture) & $\begin{array}{l}\text { Hatching- } \\
50 \text { days } \\
\text { posthatch }\end{array}$ & - & Daily & $\begin{array}{l}\text { Morphometric } \\
\text { characters; } \\
\text { total length }\end{array}$ & Acipenser stellatus & - & $\begin{array}{l}\text { Allometric growth } \\
\text { model; piecewise } \\
\text { linear regression } \\
\text { analysis; principal } \\
\text { component } \\
\text { analysis (PCA) }\end{array}$ \\
\hline $\begin{array}{l}\text { Modelling the } \\
\text { dispersal of } \\
\text { riverine fish } \\
\text { larvae }\end{array}$ & Video recordings & $\begin{array}{l}\text { 23-43 days } \\
\text { posthatch }\end{array}$ & Day-night & Daily & $\begin{array}{l}\text { Individual position; } \\
\text { movement } \\
\text { pattern }\end{array}$ & Chondrostoma nasus & - & $\begin{array}{l}\text { 3D hydrodynamic model } \\
\text { RSim-3D; numerical } \\
\text { particle tracing } \\
\text { model; raster-based } \\
\text { analysis of movement } \\
\text { patterns }\end{array}$ \\
\hline $\begin{array}{l}\text { Spatial distribution } \\
\text { patterns and } \\
\text { dispersal during } \\
\text { the egg phase as } \\
\text { an indication for } \\
\text { spawning } \\
\text { ground extent }\end{array}$ & $\begin{array}{l}\text { Gulf III-Nackthai; } \\
\text { Gulf VII; bongo; } \\
\text { WP2 nets }\end{array}$ & January-March & - & - & Eggs $\cdot \mathrm{m}^{-2}$ & $\begin{array}{l}\text { Gadus morhua, } \\
\text { Melanogrammus } \\
\text { aeglefinus, } \\
\text { Merlangius } \\
\text { merlangus, } \\
\text { Pleuronectes } \\
\text { platessa }\end{array}$ & $\begin{array}{l}\text { Identification key; } \\
\text { genetic } \\
\text { fingerprinting } \\
\text { (cytochrome } b \\
\text { PCR-RFLP) }\end{array}$ & $\begin{array}{l}\text { Spatial autocorrelation } \\
\text { (Moran's eigenvector } \\
\text { maps); generalized } \\
\text { additive mixed } \\
\text { model (GAMM) }\end{array}$ \\
\hline $\begin{array}{l}\text { Temporal } \\
\text { variability of } \\
\text { larval drift }\end{array}$ & Drift net & 12 months & $24 \mathrm{~h}$ & $\begin{array}{c}\text { Each } 2-4 \mathrm{~h} \text { for } \\
1-20 \mathrm{~min}\end{array}$ & $\begin{array}{l}\text { Larval flow, } q_{\text {larvae }} \\
\quad \text { (individuals } \cdot \mathrm{s}^{-1} \text { ) }\end{array}$ & Sicydiinae & DNA & $\begin{array}{l}\text { Periodic linear } \\
\text { regression }\end{array}$ \\
\hline $\begin{array}{l}\text { Otolith } \\
\text { microchemistry } \\
\text { to identify } \\
\text { sources of larval } \\
\text { production }\end{array}$ & Push-net trawls & $\begin{array}{r}\text { May-June; } \\
\text { October }\end{array}$ & Day & - & $\begin{array}{l}\text { Individuals per } \\
\text { volume; otolith } \\
\text { microchemistry }\end{array}$ & Perca flavescens & Identification key & $\begin{array}{l}\text { Multivariate analysis of } \\
\text { variance (MANOVA); } \\
\text { regularized } \\
\text { discriminant analysis }\end{array}$ \\
\hline $\begin{array}{l}\text { The influence of } \\
\text { discharge, current } \\
\text { speed, and } \\
\text { development on } \\
\text { the downstream } \\
\text { dispersal of larvae }\end{array}$ & Drift nets & April-June & $\begin{array}{l}\text { Dusk- } \\
\text { midnight }\end{array}$ & Hourly & $\begin{array}{l}\text { Individuals per } \\
\text { volume (i.e., } \\
\text { individuals. } \\
100 \mathrm{~m}^{-3} \text { ) }\end{array}$ & Chondrostoma nasus & - & $\begin{array}{c}\text { Mark-release-recapture } \\
\text { approach; differences } \\
\text { between recaptured } \\
\text { larvae and passive } \\
\text { particles; generalized } \\
\text { linear model (GLM) }\end{array}$ \\
\hline $\begin{array}{l}\text { Downstream } \\
\text { migration and } \\
\text { mechanisms of } \\
\text { dispersal of } \\
\text { young fish }\end{array}$ & Drift nets & May-August & $\begin{array}{l}\text { Day-night } \\
\quad(24 \mathrm{~h})\end{array}$ & Hourly & $\begin{array}{l}\text { Individuals; } \\
\text { hormonal state }\end{array}$ & Multitaxa - species & Identification key & $\begin{array}{l}\text { Temporal and spatial } \\
\text { occurrence and } \\
\text { abundance }\end{array}$ \\
\hline $\begin{array}{l}\text { The ecology of } \\
\text { oceanic dispersal } \\
\text { and survival of } \\
\text { anguillid } \\
\text { leptocephali }\end{array}$ & Various & - & - & - & Various & $\begin{array}{l}\text { Several Anguilla } \\
\text { species }\end{array}$ & - & $\begin{array}{l}\text { Spatiotemporal } \\
\text { distribution and } \\
\text { dispersal; modelling } \\
\text { dispersal; influences } \\
\text { on survival }\end{array}$ \\
\hline
\end{tabular}




\begin{tabular}{|c|c|c|c|c|c|c|c|c|}
\hline Topic & Sampling method & $\begin{array}{l}\text { Sampling } \\
\text { period }\end{array}$ & Daily period & $\begin{array}{l}\text { Sampling } \\
\text { interval }\end{array}$ & Parameter & Taxa & $\begin{array}{l}\text { Species } \\
\text { identification }\end{array}$ & $\begin{array}{l}\text { Analysis-statistical } \\
\text { procedures }\end{array}$ \\
\hline $\begin{array}{l}\text { Clustered reef fish } \\
\text { recruitment }\end{array}$ & $\begin{array}{l}\text { Stobutzki and Bellwood } \\
\text { light traps }\end{array}$ & July-August & $\begin{array}{l}\text { Dusk- } \\
\text { midnight }\end{array}$ & $15 \mathrm{~min}$ & Fish counts & Multitaxa — species & Identification key & $\begin{array}{l}\text { Index of aggregation; } \\
\text { distance to crowding } \\
\text { index; degree of } \\
\text { clustering; spatial } \\
\text { analysis by distance } \\
\text { indices (SADIE } \\
\text { association index) }\end{array}$ \\
\hline $\begin{array}{l}\text { Larval fish } \\
\text { dispersal along } \\
\text { an estuarine-- } \\
\text { ocean gradient }\end{array}$ & $\begin{array}{l}\text { Towed plankton net; } \\
\text { Bongo net; fitted with } \\
\text { flowmeters }\end{array}$ & April & $\begin{array}{l}\text { Day-night } \\
(24 \mathrm{~h})\end{array}$ & Continuous & $\begin{array}{l}\text { Individuals per } \\
\text { volume (i.e., } \\
\text { individuals. } \\
100 \mathrm{~m}^{-3} \text { ) }\end{array}$ & Multitaxa - species & Identification key & $\begin{array}{l}\text { Kruskal-Wallis analysis } \\
\text { of variance ANOVA; } \\
\text { canonical } \\
\text { correspondence } \\
\text { analysis (CCA) }\end{array}$ \\
\hline $\begin{array}{l}\text { Dispersal and } \\
\text { distribution of } \\
\text { larval fish }\end{array}$ & $\begin{array}{l}\text { Towed plankton net } \\
\text { combined with a flow } \\
\text { meter }\end{array}$ & 12 months & $\begin{array}{l}\text { Daytime } \\
\text { during the } \\
\text { ebb tide }\end{array}$ & $\begin{array}{l}\text { Each new moon, } \\
\text { one sample } \\
\text { per site on } \\
3 \text { consecutive } \\
\text { days }\end{array}$ & $\begin{array}{l}\text { Individuals per } \\
\text { volume (i.e., } \\
\text { individuals. } \\
100 \mathrm{~m}^{-3} \text { ) }\end{array}$ & Multitaxa — species & Identification key & $\begin{array}{l}\text { Permutational } \\
\text { multivariate analysis } \\
\text { of variance } \\
\text { (PERMANOVA); } \\
\text { principle component } \\
\text { analysis (PCA); CCA }\end{array}$ \\
\hline $\begin{array}{l}\text { Mesoscale eddies } \\
\text { as retention } \\
\text { mechanisms for } \\
\text { fish larvae }\end{array}$ & $\begin{array}{l}\text { Multiple opening closing } \\
\text { net and environmental } \\
\text { sensing system } \\
\text { (MOCNESS); modified } \\
\text { inshore frame net }\end{array}$ & May-August & - & - & Larvae $\cdot \mathrm{m}^{-2}$; age & Multitaxa — species & Identification key & $\begin{array}{l}\text { ANOVA; PCA; analysis of } \\
\text { similarity (ANOSIM); } \\
\text { similarity } \\
\text { percentages (SIMPER); } \\
\text { nonmetric } \\
\text { multidimensional } \\
\text { scaling (NMDS) }\end{array}$ \\
\hline $\begin{array}{l}\text { Tracing the drift of } \\
\text { eel larvae during } \\
\text { the year of } \\
\text { spawning }\end{array}$ & $\begin{array}{l}\text { Isaacs-Kidd midwater } \\
\text { trawl (IKMT) }\end{array}$ & $\begin{array}{l}3 \text { consecutive } \\
\text { years for } \\
\text { March-April }\end{array}$ & - & - & $\begin{array}{l}\text { Individual position; } \\
\text { total length; } \\
\text { growth rate }\end{array}$ & $\begin{array}{l}\text { Anguilla anguilla, } \\
\text { Anguilla rostrata }\end{array}$ & $\begin{array}{l}\text { Identification key; } \\
\text { 18S rDNA } \\
\text { genotyping }\end{array}$ & $\begin{array}{l}\text { Backtracking simulation } \\
\text { on the basis of two } \\
\text { ocean models (Hybrid } \\
\text { Coordinate Ocean } \\
\text { Model, operational } \\
\text { Mercator global ocean } \\
\text { analysis and forecast } \\
\text { system) }\end{array}$ \\
\hline $\begin{array}{l}\text { Influences of the } \\
\text { Three Gorges } \\
\text { Dam on drifting } \\
\text { larvae }\end{array}$ & Ichthyologic trap net & $\begin{array}{l}\text { April- } \\
\text { September }\end{array}$ & $\begin{array}{l}\text { Day-night } \\
(24 \mathrm{~h})\end{array}$ & $\begin{array}{l}\text { (Thrice) } \\
\text { monthly; } \\
\text { every } 8 \mathrm{~h}\end{array}$ & $\begin{array}{l}\text { Individuals per } \\
\text { volume (i.e., } \\
\text { individuals. } \\
1000 \mathrm{~m}^{-3} \text { ); otolith } \\
\text { increments }\end{array}$ & $\begin{array}{l}\text { Mylopharyngodon } \\
\text { piceus, } \\
\text { Ctenopharyngodon } \\
\text { idella, } \\
\text { Hypophthalmichthys } \\
\text { molitrix, } \\
\text { Hypophthalmichthys } \\
\text { nobilis }\end{array}$ & Identification key & $\begin{array}{l}\text { Temporal and spatial } \\
\text { occurrence and } \\
\text { abundance }\end{array}$ \\
\hline $\begin{array}{l}\text { Movement patterns } \\
\text { and rheoreaction } \\
\text { of larvae of a } \\
\text { fluvial specialist }\end{array}$ & Video recording & $\begin{array}{l}\text { 23-43 days } \\
\text { posthatch }\end{array}$ & Day-night & Daily & $\begin{array}{l}\text { Individual position; } \\
\text { movement } \\
\text { pattern }\end{array}$ & Chondrostoma nasus & - & $\begin{array}{l}\text { Image analysis; } \\
\text { frequency } \\
\text { distribution; GLM }\end{array}$ \\
\hline
\end{tabular}


served as a basis of a correlated random walk model (Glas et al. 2017), which, when coupled with a 3D hydrodynamic model, enable prediction of the effects of discharge, bed morphology, as well as restoration measures on the distribution patterns of the early stages of fish in rivers. Lechner et al. (2018) show in their field experiment that the drift mode and spatial drift patterns of marked and recaptured larvae differ substantially from simultaneously released, passively drifting plastic particles. In this environment, the interrelationship of discharge and inshore morphology are relevant factors that influence the dispersal of the early stages. These findings have important implications for river management, especially in light of human alterations in this system.

In their study on the drift and dispersal of fish larvae downstream of the Three Georges Dam, China, Song et al. (2018) observed a gradient of larval abundance, a temporal shift of peak abundance, as well as changes in the growth rates of four fish species with increasing distance from the dam. As the reproductive output from a historical spawning area close to the dam was reduced, the role and function of tributaries located further downstream became more important for recruitment of these important species.

Tributaries play a highly decisive role for amphidromous fish species, even in an island environment. Accessibility and connectivity of tributaries have direct effects on the species occurrence and recruitment. Lagarde et al. (2017) report that larvae of amphidromous gobies predominantly disperse during the period of highest flow, which can be interpreted as a strategy to reduce the risk of predator-induced mortality. They show that larval drift measurements provide qualitative information about spawning and growing habitats located upstream and enable the evaluation of species richness of the river system.

River estuaries are important transition zones with a highly diverse fish fauna, which benefits from a high productivity, and serve as nursery areas for marine as well as freshwater species. Ramos et al. (2017) show that for the dispersal of the offspring of migrant species, connectivity and seasonal conditions are important factors, and Rousseau et al. (2018) found a high portion of co-occurring species that spend their whole life in the estuary, probably with a low dispersion of larvae.

Previous literature reviews have suggested that future experimental work should focus on the processes involved in larval fish navigation and motion capacities and their internal state (Lechner et al. 2016). Such information is essential to improve biophysical models, which are a powerful tool for understanding dispersal, and will shed light on movement paths and settlement behaviour.

In this context, a detailed knowledge of early ontogeny of a single species is advantageous, as morphological features correlate with the development of sensory, feeding, and respiratory systems and thus relevant behavioural (orientation) and movement (swimming) capabilities. Eshaghzadeh et al. (2017) apply a new analytical method that defines different growth stanzas from morphometric characters of a highly endangered, commercially important species. Data from this type of study can be used to relate the timing of development with field observations (i.e., initiation of drift, settlement, etc.). Piercy et al. (2018) shed new light on the process of settlement for fish settling to reefs. By increasing the temporal resolution of settlement sampling, they reveal a highly clustered, species-specific temporal pattern of settlement.

This special issue presents an update of the urgently needed knowledge of dispersal ecology of the early life stages of fishes for further understanding of population dynamics, fisheries management, and state of the art drift model development and application required for better environmental protection and species conservation, as well as restoration ecology.

\section{References}

An asterisk (*) indicates references that are from the special issue "Dispersal during early life history of fish".

*Eshaghzadeh, H., Alcaraz, C., Akbarzadeh, A., and Gisbert, E. 2017. The combination of bivariate and multivariate methods to analyze character synchronization and early allometric growth patterns in the stellate sturgeon (Acipenser stellatus) as tools for better understanding larval behavior. Can. J. Fish. Aquat. Sci.74(10): 1528-1537. doi:10.1139/cjfas-2016-0288.

*Glas, M., Tritthart, M., Zens, B., Keckeis, H., Lechner, A., Kaminskas, T., and Habersack, H. 2017. Modelling the dispersal of riverine fish larvae: from a raster-based analysis of movement patterns within a racetrack flume to a rheoreaction-based correlated random walk (RCRW) model approach. Can. J. Fish. Aquat. Sci. 74(9): 1474-1489. doi:10.1139/cjfas-2016-0287.

*Höffle, H., Van Damme, C.J., Fox, C.J., Lelièvre, S., Loots, C., Nash, R.D., Vaz, S., Wright, J., and Munk, P. 2018. Linking spawning ground extent to environmental factors - patterns and dispersal during the egg phase of four North Sea fishes. Can. J. Fish. Aquat. Sci. 75(3). [Online ahead of print.] doi:10.1139/ cjfas-2016-0310.

*Lagarde, R., Teichert, N., Grondin, H., Magalon, H., Pirog, A., and Ponton, D. 2017. Temporal variability of larval drift of tropical amphidromous gobies along a watershed in Réunion Island. Can. J. Fish. Aquat. Sci. 74(6): 948-957. doi:10.1139/cjfas-2016-0101.

${ }^{*}$ Lazartigues, A., Girard, C., Brodeur, P., Lecomte, F., Mingelbier, M., and Sirois, P. 2018. Otolith microchemistry to identify sources of larval yellow perch in a fluvial lake: an approach towards freshwater fish management. Can. J. Fish. Aquat. Sci. 75(3). [Online ahead of print.] doi:10.1139/cjfas-2016-0289.

Lechner, A., Keckeis, H., and Humphries, P. 2016. Patterns and processes in the drift of early developmental stages of fish in rivers: a review. Rev. Fish Biol. Fish. 26: 471-489. doi:10.1007/s11160-016-9437-y.

*Lechner, A., Keckeis, H., Glas, M., Tritthart, M., Habersack, H., Andorfer, L., and Humphries, P. 2018. The influence of discharge, current speed, and development on the downstream dispersal of larval nase (Chondrostoma nasus) in the River Danube. Can. J. Fish. Aquat. Sci. 75(2). [Online ahead of print.] doi:10. 1139/cjfas-2016-0340.

Leis, J.M., Siebeck, U., and Dixson, D.L. 2011. How Nemo finds home: The neuroecology of dispersal and of population connectivity in larvae of marine fishes. Integr. Comp. Biol. 51(5): 826-843. doi:10.1093/icb/icr004. PMID:21562025.

**Miller, M.J., and Tsukamoto, K. 2017. The ecology of oceanic dispersal and survival of anguillid leptocephali. Can. J. Fish. Aquat. Sci. 74(6): 958-971. doi:10.1139/cjfas-2016-0281.

*Pavlov, D.S., and Mikheev, V.N. 2017. Downstream migration and mechanisms of dispersal of young fish in rivers. Can. J. Fish. Aquat. Sci. 74(8): 1312-1323. doi:10.1139/cjfas-2016-0298.

*Piercy, J.J.B., Smith, D.J., Jompa, J., Simpson, S.D., and Codling, E.A. 2018. High temporal resolution sampling reveals reef fish settlement is highly clustered. Can. J. Fish. Aquat. Sci. 75(4). [Online ahead of print.] doi:10.1139/cjfas-20160318.

Pineda, J., Hare, J.A., and Sponaugle, S. 2007. Larval transport and dispersal in the coastal ocean and consequences for population connectivity. Oceanography, 20(3): 22-39. doi:10.5670/oceanog.2007.27.

**amos, S., Paris, C.B., and Angélico, M.M. 2017. Larval fish dispersal along an estuarine-ocean gradient. Can. J. Fish. Aquat. Sci. 74(9): 1462-1473. doi:10. 1139/cjfas-2016-0325.

*Rousseau, Y., Blanchard, F., and Gardel, A. 2018. Spatiotemporal dynamics of larval fish in a tropical estuarine mangrove: example of the Mahury River Estuary (French Guiana). Can. J. Fish. Aquat. Sci. 75(2). [Online ahead of print.] doi:10.1139/cjfas-2016-0267.

Schiemer, F., Keckeis, H., Reckendorfer, W., and Winkler, G. 2001. The "inshore retention concept" and its significance for large rivers. Arch. Hydrobiol. 135(Suppl. 2-4): 509-516. doi:10.1127/1r/12/2001/509.

Schludermann, E., Tritthart, M., Humphries, P., and Keckeis, H. 2012. Dispersal and retention of larval fish in a potential nursery habitat of a large temperate river: an experimental study. Can. J. Fish. Aquat. Sci. 69(8): 1302-1315. doi:10. 1139/f2012-061.

*Shulzitski, K., Sponaugle, S., Hauff, M., Walter, K.D., D’Alessandro, E.K., and Cowen, R.K. 2018. Patterns in larval reef fish distributions and assemblages, with implications for local retention in mesoscale eddies. Can. J. Fish. Aquat. Sci. 75(2). [Online ahead of print.] doi:10.1139/cjfas-2016-0304.

**Song, Y., Cheng, F., Murphy, B.R., and Xie, S. 2018. Downstream effects of the Three Gorges Dam on larval dispersal, spatial distribution, and growth of the four major Chinese carps call for reprioritizing conservation measures. Can. J. Fish. Aquat. Sci. 75(1): 141-151. doi:10.1139/cjfas-2016-0278.

*Westerberg, H., Pacariz, S., Marohn, L., Fagerström, V., Wysujack, K., Miller, M.J., Freese, M., Pohlmann, J., and Hanel, R. 2018. Modeling the drift of European (Anguilla anguilla) and American (Anguilla rostrata) eel larvae during the year of spawning. Can. J. Fish. Aquat. Sci. 75(2). [Online ahead of print.] doi:10.1139/ cjfas-2016-0256.

*Zens, B., Glas, M., Tritthart, M., Habersack, H., and Keckeis, H. 2018. Movement patterns and rheoreaction of larvae of a fluvial specialist (nase, Chondrostoma nasus): the role of active versus passive components of behaviour in dispersal. Can. J. Fish. Aquat. Sci. 75(2). [Online ahead of print.] doi:10.1139/cjfas-20160276. 